\title{
Macromolecular synthesis during recovery of the marine Vibrio sp. S14 from starvation
}

\author{
Nan H. Albertson, Thomas Nyström* and Staffan KJelleberg \\ Department of General and Marine Microbiology, University of Göteborg, Carl Skottsbergs Gata 22, \\ S-413 19 Göteborg, Sweden \\ (Received 16 May 1990; revised 16 July 1990; accepted 20 July 1990)
}

\begin{abstract}
The recovery of Vibrio sp. S14 cells from energy- and nutrient-starvation was monitored after the addition of glucose minimal medium. Upshift experiments were done throughout a starvation period of $200 \mathrm{~h}$ to determine whether cells were more responsive to nutrient addition at the onset of starvation, or if the previously described programme of starvation-induced cellular reorganization had to be completed before cells could become committed to recovery following nutritional upshifts. The kinetics of macromolecular synthesis (RNA, protein and DNA), the rate of respiration and changes in median cell volume in response to nutritional upshifts at different times of starvation were examined. The relative rates of RNA and protein synthesis increased immediately upon addition of glucose minimal medium; the increase in protein synthesis was not dependent on a parallel increase in RNA synthesis, indicating that the starved cells may have an excess of protein synthesizing machinery, including stable RNA and functional ribosomes. The subsequent increase in the rate of DNA replication was initiated approximately $60 \mathrm{~min}$ before the first apparent cell division at approximately one doubling of the theoretical minimal cell volume $\left(V_{u}\right)$. Two-dimensional gel electrophoresis was used to demonstrate the fate of starvationspecific proteins during the upshift, and also the synthesis of recovery-induced proteins that were not found in starving cells. Most starvation-inducible proteins were repressed immediately at the onset of the nutritional upshift, while 11 of the 21 recovery-induced proteins identified were expressed exclusively during the maturation phase and were subsequently repressed at the onset of regrowth. The possible role of such maturation-specific proteins in the rapid formation of a reproductive cell committed to growth and division is discussed.
\end{abstract}

\section{Introduction}

The marine environment challenges its resident microorganisms with many extremes, including temperature, hydrostatic pressure, and, perhaps most importantly, nutrient availability. Yet heterotrophic, copiotrophic bacteria have been found to survive nutrient-depleted conditions for prolonged periods (e.g. Jones \& RhodesRoberts, 1981; Morita, 1982; Kjelleberg et al., 1987). Bacteria that grow and multiply in the presence of an abundance of nutrients have been referred to as copiotrophs (Poindexter, 1981a), while oligotrophic bacteria are capable of growing in extremely low substrate concentrations (Kuznetsov et al., 1979; Poindexter, $1981 \mathrm{~b}$ ). The copiotrophs, however, can persist during nutrient exhaustion by entering a stage of non-growth via the process referred to as starvation

Abbreviation: Rif, rifampicin. survival (Morita, 1982). Two important aspects of starvation survival are that the copiotrophic organisms must preserve their genomes during prolonged periods of energy and nutrient exhaustion, and also 'retain the ability to quickly metabolize substrates' that sporadically become available (Morita, 1982).

Starvation survival has been described in several marine bacterial strains, including the marine psychrophilic Vibrio Ant-300 (Novitsky \& Morita, 1977; Amy et al., 1983a), and the mesophilic Vibrio sp. S14. The latter strain responds to starvation conditions by a complex reorganization of metabolic activities including synthesis and degradation of proteins (Nyström et al., 1988, 1989), fatty acids (Malmcrona-Friberg et al., 1986), DNA (Mårdén et al., 1988), and cell wall peptidoglycan (Nyström \& Kjelleberg, 1989). These adjustments result in a developmental form which is highly adapted for survival and is resistant to multiple stress conditions including ampicillin-induced autolysis (Nyström \& Kjelleberg, 1989), sonic lysis (Nyström \& Kjelleberg, 
1989), heat-shock and near-UV irradiation (T. Nyström, unpublished). The metabolic realignments may be important not only in securing the viability of the cells during starvation, but also in making the cells more efficient scavengers of scarce nutrients. Some of the physiological changes demonstrated by members of the family Vibrionaceae in response to starvation indicate the importance of recovery-related and substrate-scavenging functions: starved cells have an increased high-affinity uptake of amino acids (Mårdén et al., 1987), an increased uptake capacity for glucose and mannose (Albertson $e t$ al., 1990a), a continuing synthesis of exoproteases (Albertson et al., 1990b) and an increased adhesion to hydrophobic surfaces (Dawson et al., 1981; Kjelleberg et al., 1982). However, the environmental triggers and the kinetics of the macromolecular changes involved in recovery are poorly understood with respect to copiotrophic, non-differentiating marine bacteria. The recovery of the marine Vibrio Ant-300 from starvation conditions was described by Amy et al. (1983b), but only with respect to changes in the amounts of macromolecules and not to the kinetics of macromolecular synthesis and the possible repression and induction of specific polypeptides during maturation and regrowth. In contrast, the germination response of Bacillus spp. spores in response to environmental triggers (e.g. Foster \& Johnstone, 1989), and the development of reproductive cells of the differentiating bacteria Rhodomicrobium vannielii, Hyphomicrobium sp. and Caulobacter crescentus (e.g. Dow et al., 1983) is under extensive genetic and biochemical examination.

This study was done to obtain data concerning maturation and regrowth of energy- and nutrient-starved Vibrio sp. S14 subjected to a nutritional upshift, and to compare this response with the germination of true differentiating bacteria. The kinetics of RNA, DNA and protein synthesis, the rate of respiration and the increase in cell volume were examined during nutritional upshifts after different times of starvation in order to elucidate whether the cells retained a sensory mechanism which allowed them to respond rapidly to nutrient inputs. In this context, we also examined the repression and induction of specific polypeptides during maturation and regrowth by the use of t'vo-dimensional gel electrophoresis of proteins from pulse-labelled cells. We identified 11 proteins with novel or markedly increased expression exclusively during the maturation phase (mat proteins) which were repressed during both growth and starvation. These mat proteins may play a significant role in the life-cycle of Vibrio sp. S14 during the transition from a starved to a reproductive state and comprise a new group of proteins in addition to the growth-related polypeptides and starvation-inducible polypeptides (sti) previously described for S14 cells (Nyström et al., 1989).

\section{Methods}

Cultivation, starvation and recovery conditions. The marine Vibrio $\mathrm{sp}$. S14 (CCUG 15956) described by Albertson et al. (1990b) was grown in the complex marine medium VNSS (Nyström et al., 1986) to the exponential phase $\left(2 \cdot 2\right.$ doublings $\mathrm{h}^{-1}, 10^{8}$ cells $\left.\mathrm{ml}^{-1}\right)$, and washed and resuspended in NSS (nine salt solution) to a density of $5 \times 10^{7}$ cells ml-1 $^{-1}$ $\left(\mathrm{OD}_{420}=0.2\right)$ as previously described (Albertson et al., 1987). The cells were starved for exogenous carbon, nitrogen and phosphorus sources simultaneously. Starved cell suspensions were recovered at different starvation times $(0-200 \mathrm{~h})$ by adding concentrated glucose minimal medium directly to the starvation flask to give the following final concentrations per litre of starvation suspension: $4.0 \mathrm{~g}$ glucose, $2.2 \mathrm{~g}$ $\left(\mathrm{NH}_{4}\right)_{2} \mathrm{SO}_{4}, 0.5 \mathrm{~g} \mathrm{~K}_{2} \mathrm{HPO}_{4}$.

Bacterial cell counts and cell volumes. Viable cell counts (c.f.u.) were made by plating the bacteria, after appropriate dilutions, on solidified VNSS media containing $1.5 \%(\mathrm{w} / \mathrm{v})$ agar. The cells remained $100 \%$ viable throughout the starvation period studied $(200 \mathrm{~h})$, and no lysis or decreased viability was observed as a consequence of the nutritional upshifts. Total cell counts and size distributions were obtained using a microcomputerized Elzone ADC-80XY particle counter, with a $12 \mu \mathrm{m}$ orifice tube.

Respiration measurements. Rates of oxygen consumption were determined using a Hansatech DWl oxygen monitor, described by Delieu \& Walker (1972). Throughout starvation, recovery and regrowth, $2 \mathrm{ml}$ samples were withdrawn and injected into the oxygen monitor; the rate of respiration was expressed as $\mu \mathrm{g} \mathrm{O}_{2}$ consumed $\mathrm{h}^{-1}$ ( $\mathrm{ml}$ cell suspension $)^{-1}$.

Determination of DNA, RNA and protein synthesis. The rate of DNA synthesis was determined by pulse-labelling, using $\left[\right.$ methyl $\left.{ }^{-3} \mathrm{H}\right]-$ thymidine $\left(\left[{ }^{3} \mathrm{H}\right] \mathrm{dT}\right)\left(0.3 \mu \mathrm{g} \mathrm{ml}^{-1} ; 4.66 \mathrm{TBq} \mathrm{mmol}^{-1}\right.$; Amersham) as previously described (Nyström \& Kjelleberg, 1989). The rate of total RNA synthesis was determined by pulse-labelling ( $30 \mathrm{~s})$ using $1.2 \mu \mathrm{g}$ $\left[5-{ }^{3} \mathrm{H}\right]$ uridine $\mathrm{ml}^{-1}$ (4.6 TBq mmol-1 $\mathrm{TH}^{-1}$ New England Nuclear). The rate of incorporation was determined by assessing the amount of radioactivity precipitable in cold $5 \%(\mathrm{w} / \mathrm{v})$ trichloroacetic acid (TCA). After incubation for $15 \mathrm{~min}$ at $0{ }^{\circ} \mathrm{C}$, samples $(200 \mu \mathrm{l})$ were collected on membrane filters as previously described (Nyström et al., 1986). The labelled uridine incorporated by the cells was also examined for resistance to alkaline hydrolysis. Protein synthesis was monitored as described by Nyström et al. (1986). The rates of RNA and protein synthesis during the initial phase of a nutritional upshift were determined in the presence of rifampicin (Rif; $330 \mu \mathrm{g} \mathrm{ml}^{-1}$ ). Rif prevents the initiation of transcription by DNA-dependent RNA polymerase while transcription that has already commenced continues to completion.

Resolution of cell proteins on two-dimensional polyacrylamide gels. At appropriate times of starvation, maturation and regrowth, a portion $(5 \mathrm{ml})$ of the culture was removed and placed in a flask containing [35] ${ }^{35}$ thionine (3.7 MBq ml-1 ; $46 \mathrm{TBq} \mathrm{mmol}^{-1}$ ), and incorporation was allowed to proceed for $20 \mathrm{~min}$. Cells that had not been starved (exponentially growing control) were labelled for $10 \mathrm{~min}$ at an $\mathrm{OD}_{420}$ of $0.3\left(10^{8}\right.$ cells $\left.\mathrm{ml}^{-1}\right)$. Bacterial pellets were dissolved in lysis buffer $[9.5 \%, \mathrm{w} / \mathrm{v}$, urea, $2 \%, \mathrm{v} / \mathrm{v}$, Nonidet P-40, $5 \%, \mathrm{v} / \mathrm{v}, \boldsymbol{\beta}$-mercaptoethanol, $1.6 \%, \mathrm{v} / \mathrm{v}$, Ampholine 5-7 (LKB), 0.4\%, v/v, Ampholine 3-10] to produce extracts for resolution on two-dimensional polyacrylamide gels by the method of O'Farrell (1975). The first dimension was an isoelectric focusing gel (IEF) containing 0.95\% each of Ampholine 5-7, Ampholine 3-10 and Servalyt 5-7 (Serva). The second dimension was a $12 \%(\mathrm{w} / \mathrm{v})$ polyacrylamide gel. Equivalent amounts of radioactivity were loaded for each matched set of gels, i.e. starvation and maturation versus the controls ( $3 \times 10^{5}$ d.p.m.). Autoradiograms (Fuji RX-film) were prepared to permit visualization of the ${ }^{35} \mathrm{~S}$-labelled proteins. 
Proteins which were found to be either repressed or induced at different times during recovery were marked and assigned letters and numbers respectively. Relative rates of synthesis of individual polypeptides were obtained by computer-assisted microdensitometry at $633 \mathrm{~nm}$ using a LKB UltroScan XL 2220. The rate of synthesis was calculated by dividing the radioactivity of each protein spot by the total radioactivity recovered from the gel

Reproducibility. Each experiment was repeated at least twice to confirm reproducibility. Representative results are presented in the Figures in this paper.

\section{Results and Discussion}

The ability (measured as an increase in cell number) of starved cells of Vibrio sp. S14 to recover from starvation following addition of glucose minimal medium was determined at different times during $200 \mathrm{~h}$ of starvation. The results of these experiments were plotted semilogarithmically to determine the lag periods before regrowth. The lag periods determined from these growth curves are summarized in Fig. 1. The lag period before regrowth $(50-60 \mathrm{~min})$ of cells starved for 1 and $2 \mathrm{~h}$ corresponded to the lag period of Vibrio $\mathrm{S} 14$ cells shifted from a rich medium to glucose minimal medium $(0 \mathrm{~h})$. Cells starved for times longer than $2 \mathrm{~h}$, however, showed progressively longer lag periods before the resumption of DNA synthesis, cell division and growth (Fig. 1).

The lag period (maturation phase) was subsequently examined in more detail with respect to macromolecular synthesis, respiration and increase in cell volume. An analysis of cells starved for $24 \mathrm{~h}$ (Fig. 2) demonstrated that an increase in the rate of respiration and the median cell volume was initiated soon after addition of glucose minimal medium. A similar immediate response in the rate of respiration has previously been demonstrated when $\mathrm{S} 14$ cells starved for $120 \mathrm{~h}$ were supplemented with protein as a source of carbon and nitrogen (Albertson $e t$ $a l ., 1990 b$ ). The relative rate of proiein synthesis increased approximately 7 -fold within the first minute when glucose minimal medium was added to cells starved for $24 \mathrm{~h}$ (Fig. 2). The rate of protein synthesis reached a new steady state after approximately $20 \mathrm{~min}$ and increased again at the time of initiation of DNA replication (Fig. 2). The same immediate increase in the rate of protein synthesis, and the subsequent kinetics of synthesis were also seen when cells starved for $200 \mathrm{~h}$ were monitored in the same experiment (not shown). To determine if the immediate increase in the rate of protein synthesis was dependent on RNA synthesized following the upshift, Rif was added to cell suspensions at the same time as the minimal medium, and the rate of both RNA and protein synthesis was monitored (Fig. $3 a, b$ ). While the rate of RNA synthesis was effectively inhibited, the relative rate of protein synthesis following the upshift

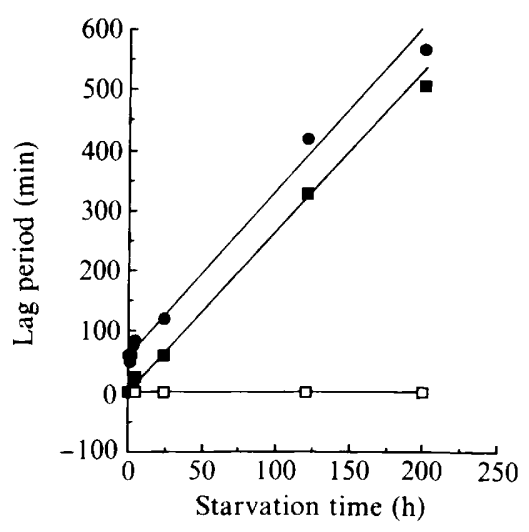

Fig. 1. Effect of starvation time on the lag period before increases in cell number $(\bullet)$, rate of DNA synthesis $(\boldsymbol{a})$ and rate of protein synthesis $(\square)$ were detected.

increased markedly, even in the presence of Rif (Fig. $3 a, b)$. This result indicates that de novo RNA synthesis was not required for the initial rapid increase in protein synthesis and that rRNA and ribosomes may exist in excess. It has previously been demonstrated that the proportionality between the number of ribosomes and the demands for protein synthesis breaks down during slow growth of Escherichia coli resulting in an excess of the protein synthesizing machinery (Koch, 1971, 1979; Maaløe, 1979). Koch (1979) suggested that the extrastable RNA in slowly growing carbon-limited $E$. coli was not involved in making proteins but may significantly increase the ability of the cells to respond rapidly to sporadic inputs of nutrients. Surprisingly, we found similar results concerning protein synthesis as a result of a nutritional upshift when Vibrio sp. S14 cells had been in a non-growing starved state for 24,120 and $200 \mathrm{~h}$. Possible changes in mRNA stability may not be involved in this response, since the starvation-induced stabilization of the mRNA pool is rapidly lost during the nutritional upshift [Albertson et al., 1990c (preceding paper)].

The progressively increased lag period preceding regrowth subsequent to starvation for $2 \mathrm{~h}$ was found to be a result of a prolonged $I$ period (the time required for a cell to prepare initiation of replication, i.e. the interinitiation time; Helmstetter et al., 1979) (Fig. 1). Once an increase in DNA synthesis was observed, the first apparent cell division occurred approximately $60 \mathrm{~min}$ later ( $\underline{C}$ and $\underline{D}$ period), regardless of how long the cells had been starved (Figs 1 and 2). DNA replication was initiated at a cell volume corresponding to approximately twice the theoretical minimal cell volume ( $V_{\mathrm{u}}$; Donachie \& Robinson, 1987) at all the starvation times studied. The $V_{\mathrm{u}}$ for Vibrio sp. S14 has previously been determined 

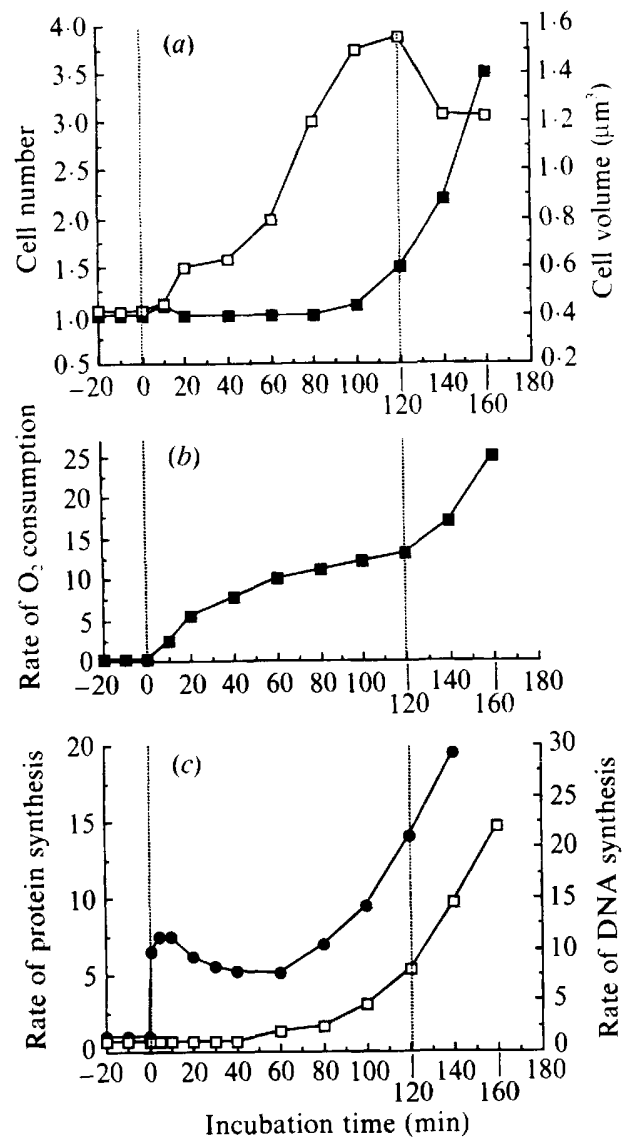

Fig. 2. Relative changes in some morphological and physiological parameters in response to a nutritional upshift of Vibrio sp. S14 cells starved for $24 \mathrm{~h}$. Time zero is the time at which a suspension of cells that had been starved for $24 \mathrm{~h}$ was supplemented with glucose minimal medium. The period between 0 and $120 \mathrm{~h}$ designates the maturation phase, after which the cells grew in a balanced mode with a cell volume characteristic for the medium and the growth rate. (a) Relative changes in cell numbers $(\square)$ and median cell volumes $(\square)$. The cell numbers were related to that obtained for starved cells prior to the upshift, which was assigned a value of $1 \cdot 0$. The absolute cell number at the onset of recovery was $5 \times 10^{7} \mathrm{ml}^{-1}$. (b) Changes in the rate of respiration measured as $\mu \mathrm{g} \mathrm{O}_{2} \mathrm{~h}^{-1}$ (ml cell suspension) $)^{-1}$. (c) Relative rates of protein (๑) and DNA ( $\square$ ) synthesis during maturation and regrowth. The relative rates of synthesis were related to the rate obtained for cells starved for $24 \mathrm{~h}$, which was assigned a value of 1.0 . The rate of $\left[{ }^{3} \mathrm{H}\right] \mathrm{dT}$ incorporation at $24 \mathrm{~h}$ starvation prior to the upshift was close to the detection limit, was not inhibited by nalidixic acid and could not be referred to as DNA replication.

to be $0.5 \mu \mathrm{m}^{3}$ (Nyström \& Kjelleberg, 1989). The time period required to reach $2 V_{u}$ during the nutritional upshifts may be prolonged during starvation as a consequence of the progressive decrease in cell volume during starvation (Nyström \& Kjelleberg, 1987). Starvation of most marine bacteria brings about the formation of ultramicrocells (Novitsky \& Morita, 1976), due to the continuous degradation of endogenous

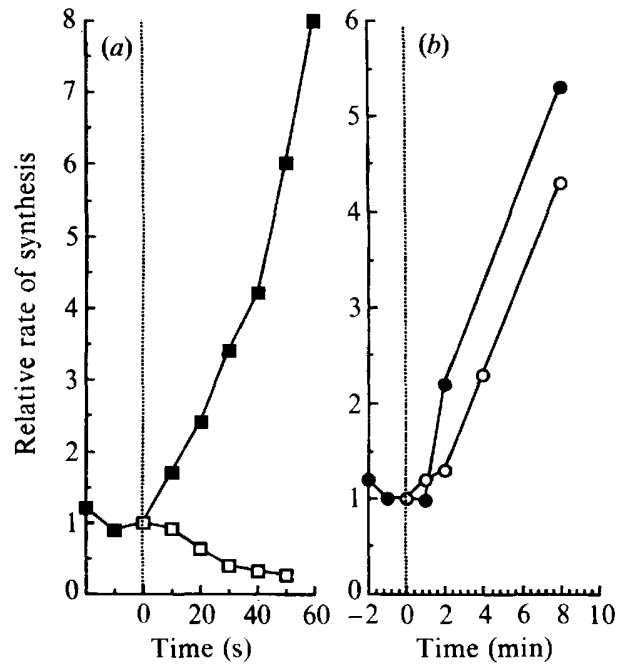

Fig. 3. Relative rate of RNA ( $a$ ) and protein $(b)$ synthesis during the initial phase of recovery of cells that had been starved for $24 \mathrm{~h}$. $\mathbf{\square}, \bullet$, Untreated cells; $\square, O$, Rif-treated cells. Cells were pulse-labelled at the times indicated in the Figure. The relative rates of synthesis were related to the rate obtained for untreated cells prior to the nutritional upshift $(0 \mathrm{~min})$.

material (Dawson et al., 1981; Kjelleberg et al., 1983; Kjelleberg \& Hermansson, 1984).

Protein synthesis during the upshift experiments was further examined using two-dimensional gel electrophoresis, which revealed that several polypeptides (A-R) were immediately repressed at the onset of the nutritional upshift (Fig. 4). Proteins $S$ and $T$ were repressed somewhat later during the maturation phase while proteins $\mathrm{U}, \mathrm{W}$, and $\mathrm{X}$ were only transiently repressed during the initial phase of maturation (Fig. 4). Several of the proteins A-T have previously been identified as starvation-inducible (sti) proteins belonging to temporal sti classes expressed at different times during starvation (Nyström et al., 1989). It was apparent that proteins from both 'early' and 'late' temporal sti classes were immediately repressed as a result of the addition of glucose minimal medium.

Twenty-one proteins were found to exhibit novel or markedly increased expression as a consequence of substrate addition (Fig. 4). These proteins are marked and numbered in the panels of Fig. 4 and are listed in Table 1. The proteins are expressed in a sequential manner during the maturation phase and can be divided into at least three temporal groups (Table 1). Groups I and II are subdivided into class ' $a$ ' which designates proteins expressed both throughout the maturation phase and during regrowth, while class ' $b$ ' denotes proteins synthesized exclusively during maturation 

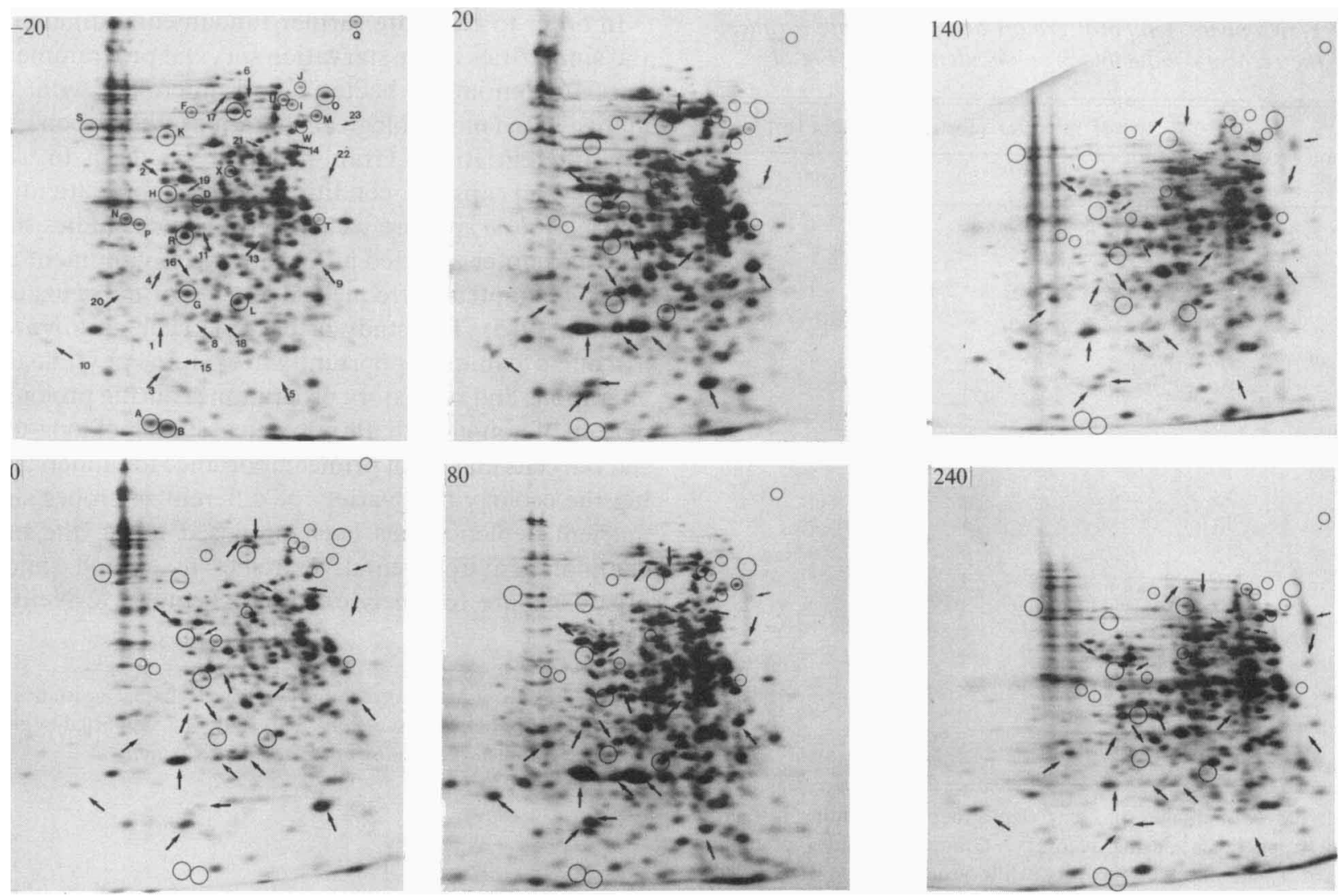

Fig. 4. Representative two-dimensional gels obtained during starvation, maturation and regrowth of Vibrio sp. S14. Cells were labelled for $20 \mathrm{~min}$ with $\left[{ }^{35} \mathrm{~S}\right]$ methionine at the times indicated; $-20 \mathrm{~min}$ denotes cells starved for $24 \mathrm{~h}$ and then labelled for $20 \mathrm{~min}$ prior to the upshift. At $240 \mathrm{~min}$, the cells were in balanced growth at a growth rate of 1.1 doublings $\mathrm{h}^{-1}$. Encircled proteins (assigned letters) were repressed during maturation; arrows show proteins (assigned numbers) which were induced during the maturation phase.

(Table 1). Accordingly, we designate the proteins belonging to groups $\mathrm{Ib}$ and $\mathrm{IIb}$ as mat polypeptides (maturation-specific). A question of interest concerning these mat proteins relates to their role in the possible reorganization of both the non-replicative nucleoid and the autolysis-resistant peptidoglycan (Nyström \& Kjelleberg, 1989) of the starved ultramicrocell. Starvation of Vibrio sp. S14 cells has been shown to promote protein-synthesis-dependent resistance against autolytic cell-wall degradation (Nyström \& Kjelleberg, 1989), a feature which must be overcome during the transition to a reproductive state. The function of some mat proteins may be to degrade specific sti proteins involved in the generation of a non-replicative nucleoid (e.g. DNAbinding proteins) and in the mechanisms of autolysis resistance. The initial events in the germination of Bacillus cereus spores have been suggested to involve such specific protease(s) (Boschwitz et al., 1985), which may be directly involved in autolysin activation (Mencher \& Blankenship, 1971). However, these proteases are environmentally activated rather than being induced during the initial phase of germination (e.g. Foster \& Johnstone, 1989).

Some of the changes that occur during both starvation and recovery of the marine Vibrio sp. S14 bear obvious similarities to sporulation and germination responses of true differentiating bacteria such as Bacillus. These starvation-induced responses include transient provocation of the stringent response and subsequent sequential expression of starvation-specific proteins (Nyström et al., 1989), increased resistance to a variety of stresses including ampicillin-induced autolysis and sonic lysis (Nyström \& Kjelleberg, 1989), heat-shock and near-UV irradiation (T. Nyström, unpublished), a reduction in the overall metabolic activity (Mårdén et al., 1985), termination of DNA replication (Mårdén et al., 1988; Nyström \& Kjelleberg, 1989) and an increased expression and secretion of exoproteases (Albertson et al., 1990 b). In terms of the recovery of starved Vibrio S14 cells, the abrupt onset of respiration, the instantaneous increase in 
Table 1. Numbers, temporal groups and time of appearance of the recovery-inducible proteins identified in Fig. 4

\begin{tabular}{cccccccc}
\hline \hline \multirow{2}{*}{$\begin{array}{c}\text { Temporal } \\
\text { group* }\end{array}$} & $\begin{array}{c}\text { Protein } \\
\text { no. }\end{array}$ & \multicolumn{6}{c}{ Time after substrate addition (h)t } \\
\cline { 3 - 8 } Ia & 1 & -20 & 0 & 20 & 80 & 140 & 240 \\
& 2 & - & + & + & + & + & + \\
Ib & 3 & - & + & + & + & + & + \\
& 4 & - & + & + & + & + & - \\
& 5 & - & + & + & + & - & - \\
& 6 & - & + & + & + & - & - \\
& 8 & - & + & + & + & - & - \\
IIa & 9 & - & + & + & + & - & - \\
& 10 & - & - & + & + & + & + \\
& 11 & - & - & + & + & + & + \\
IIb & 13 & - & - & + & + & + & + \\
& 14 & - & - & + & + & + & + \\
& 15 & - & - & + & + & + & - \\
& 16 & - & - & + & + & - & - \\
& 17 & - & - & + & + & - & - \\
III & 18 & - & - & + & + & - & - \\
& 19 & - & - & + & + & - & - \\
& 20 & - & - & - & + & + & + \\
& 21 & - & - & - & + & + & + \\
& 22 & - & - & - & + & + & + \\
& 23 & - & - & - & - & + & + \\
\hline \hline
\end{tabular}

* All recovery-inducible proteins were grouped according to their time of appearance during recovery. Group I includes proteins expressed at the onset of recovery while groups II and III denote recovery-inducible proteins expressed later during the nutritional upshift. The ' $a$ ' designation identifies proteins expressed throughout the maturation phase and during subsequent regrowth, while ' $b$ ' denotes maturation-specific (mat) proteins which were induced at different times during the nutritional upshift and subsequently repressed at the onset of growth.

+ Protein numbers are the same as those in Fig. 4.

$\ddagger$ Cells were labelled for $20 \mathrm{~min}$ at the time indicated in the Table; $-20 \mathrm{~min}$ denotes cells starved for $24 \mathrm{~h}$ pulse-labelled for $20 \mathrm{~min}$ prior to the nutritional upshift.

RNA and protein synthesis but not DNA replication (this paper) and the abrupt fall in heat resistance (T. Nyström, unpublished) is strikingly similar to several principal events in the germination of the bacterial spore (Gould, 1970). It should be pointed out, however, that there are several principal differences between the germination of a spore and the maturation and regrowth of the starved ultramicrocell. Even long-term $(200 \mathrm{~h})$ starved cells of Vibrio S14 are not dormant: they demonstrate a low but readily detected level of both RNA and protein synthesis; they do not need specific activation conditioning (e.g. heat, extremes in $\mathrm{pH}$, reducing agents) other than the input of nutrients to initiate maturation; they are able to take up nutrients in concentrations below the threshold levels for growth at any time during $120 \mathrm{~h}$ of energy and nutrient starvation (Mårdén et al., 1987; Albertson et al., 1990a).
In order to elucidate further fundamental differences and similarities in the starvation survival programmes of true differentiating bacteria and microbes with less sophisticated morphological alterations, the responses of non-differentiating, Gram-negative bacteria to starvation and upshift conditions need more attention. Marine Vibrio spp. are well-suited for such studies since they encounter a varied and changing environment and are well-adapted to frequent depletion of nutrients (e.g. Morita, 1985). The study of bacteria such as Vibrio sp. S14 offers a unique opportunity to examine physiological alterations and regulatory programmes during prolonged periods of non-growth. Physiological studies of long-term starved cells may be of prime importance for understanding the ecology of a variety of different microbes since nutrient depletion has been proposed to be the most common environmental extreme to which microorganisms are routinely exposed' (Tempest \& Neijssel, 1981).

We thank Rose Marie Olsson for excellent technical assistance and Klas Flärdh for helpful discussions. This study was supported by grants from the Swedish Natural Science Research Council.

\section{References}

Albertson, N. H., Jones, G. W. \& Kuelleberg, S. (1987). The detection of starvation specific antigens in two marine bacteria. Journal of General Microbiology 133, 2225-2231.

Albertson, N. H., Nyström, T. \& KJelleberG, S. (1990a). Starvation-induced modulations in binding protein-dependent glucose transport by the marine Vibrio sp. S14. FEMS Microbiology Letters 70, 205-210.

AlberTson, N. H., NyStröM, T. \& KJelleberg, S. $(1990 b)$. Exoprotease activity during starvation of two marine bacteria. Applied and Environmental Microbiology 56, 218-223.

Albertson, N. H., NyströM, T. \& KJelleberg, S. $(1990 c)$. Functional mRNA half-lives in the marine Vibrio sp. S14 during starvation and recovery. Journal of General Microbiology 136, 2195-2199.

Amy, P. S., Pauling, C. \& Morita, R. Y. (1983a). Starvation-survival processes of a marine Vibrio. Applied and Environmental Microbiology 45, 1041-1048.

Amy, P. S., Pauling, C. \& Morita, R. Y. (1983b). Recovery from nutrient starvation by a marine Vibrio sp. Applied and Environmental Microbiology 45, 1685-1690.

Boschwitz, H., Halvorson, H. O., Keynan, A. \& Milner, Y. (1985), Trypsin-like enzymes from dormant and germinated spores of Bacillus cereus $\mathrm{T}$ and their possible involvement in germination. Journal of Bacteriology 164, 302-309.

Dawson, M. P., Humphrey, B. A. \& Marshall, K. C. (1981). Adhesion: a tactic in the survival strategy of a marine vibrio during starvation. Current Microbiology 6, 195-199.

Delieu, T. \& Walker, D. A. (1972). An improved cathode for the measurement of photosynthetic oxygen evolution by isolated chloroplasts. New Phytology 71, 201-205.

DonachiE, W. D. \& Robinson, A. C. (1987). Cell division : parameter values and the process. In Escherichia coli and Salmonella typhimurium, Cellular and Molecular Biology, vol. 2, pp. 1578-1593. Edited by F. C. Neidhardt. Washington, DC: American Society for Microbiology. 
Dow, C. S., Whirtenbury, R. \& CARR, N. G. (1983). The 'shut down' or 'growth precursor' cell - an adaptation for survival in a potentially hostile environment. Symposia of the Society for General Microbiology 34, 187-247.

FOSTER, S. J. \& JohNSTONE, K. (1989). The trigger mechanism of bacterial spore germination. In Regulation of Prokaryotic Development, pp. 89-107. Edited by I. Smith, R. A. Slepecky \& P. Setlow. Washington, DC: American Society for Microbiology.

Gould, G. W. (1970). Germination and the problem of dormancy. Journal of Applied Bacteriology 33, 34-49.

Helmstetter, C. E., Pierucci, O., Weinberger, M., Holmes, M. \& TANG, M.-S. (1979). Control of cell division in Escherichia coli. In The Bacteria, vol. 7, pp. 517-579. Edited by J. R. Sokatch \& L. N. Ornston. New York: Academic Press.

JoNES, K. L. \& RHodes-RoberTS, M. E. (1981). The survival of marine bacteria under starvation conditions. Journal of Bacteriology $\mathbf{5 0}$, $247-258$.

KJelleberg, S. \& Hermansson, M. (1984). Starvation-induced effects on bacterial surface characteristics. Applied and Environmental Microbiology 48, 497-503.

KJelleberG, S., Humphrey, B. A. \& Marshall, K. C. (1982). Effects of interfaces on small, starved marine bacteria. Applied and Environmental Microbiology 43, 1166-1172.

KJElleberg, S., Humphrey, B. A. \& MarShall, K. C. (1983). Initial phase of starvation and activity of bacteria at surfaces. Applied and Environmental Microbiology 46, 978-984.

KJelleberG, S., HermansSON, M., MÅrdén, P. \& Jones, G. W. (1987). The transient phase between growth and nongrowth of heterotrophic bacteria, with emphasis on the marine environment. Annual Review of Microbiology 41, 25-49.

KoCH, A. L. (1971). The adaptive response of Escherichia coli to a feast and famine existence. Advances in Microbial Physiology 6, 147-217.

KoCH, A. L. (1979). Microbial growth at low concentrations of nutrients. In Strategies of Microbial Life in Extreme Environments, Dahlem Konferenzen, pp. 261-279. Edited by M. Shilo. Weinheim: Verlag Chemie.

Kuznetsov, S. I., Dubina, A. G. \& Lapteva, N. A. (1979). Biology of oligotrophic bacteria. Annual Review of Microbiology 33, 377-387.

MAALøE, O. (1979). Regulation of the protein-synthesizing machineryribosomes, tRNA, factors and so on. In Biological Regulation and Development, vol. 1. Edited by R. F. Goldberger. New York: Plenum Press.

Malmcrona-Friberg, K., Tunlid, A., MÅrdén, P., Kuelleberg, S. \& ODHAM, G. (1986). Chemical changes in the cell envelope and poly- $\beta$-hydroxybutyrate during short term starvation of a marine bacterial isolate. Archives of Microbiology 144, 340-345.

Mårdén, P., Tunlid, A., Malmcrona-Friberg, K., Odham, G. \& KJelLeberg, S. (1985). Physiological and morphological changes during short term starvation of marine bacterial isolates. Archives of Microbiology 142, 326-332.
MÅrdÉn, P., Nyström, T. \& KJeLleberg, S. (1987). Uptake of leucine by a marine Gram-negative heterotrophic bacteria isolated from marine waters. FEMS Microbiology Ecology 45, 233-241.

Mårdén, P., Hermansson, M. \& KJelleberg, S. (1988). Incorporation of tritiated thymidine by marine bacterial isolates when undergoing a starvation survival response. Archives of Microbiology 149, 427-432.

Mencher, J. R. \& Blankenship, L. C. (1971). Enhancement of Bacillus cereus spore lytic enzyme by heat labile non-dialysable factor in spore extracts. Biochimica et Biophysica Acta 230, 646-648.

MoRITA, R. Y. (1982). Starvation-survival of heterotrophs in the marine environment. Advances in Microbial Ecology 6, 171-198.

MORITA, R. Y. (1985). Starvation and miniaturisation of heterotrophs, with special emphasis on maintenance of the starved viable state. In Bacteria in Their Natural Environments, pp. 111-130. Edited by M. M. Fletcher \& G. D. Floodgate. London: Academic Press.

NovitSKy, J. A. \& MoRITA, R. Y. (1976). Morphological characterization of small cells resulting from nutrient starvation of a psychrophilic marine vibrio. Applied and Environmental Microbiology 32, $617-622$.

Novitsky, J. A. \& MoritA, R. Y. (1977). Survival of a psychrophilic marine vibrio under long-term nutrient starvation. Applied and Environmental Microbiology 33, 635-641.

NySTRÖM, T. \& KJELleberG, S. (1987). The effect of cadmium on starved heterotrophic bacteria isolated from marine waters. FEMS Microbiology Ecology 45, 143-151.

NyströM, T. \& K JELLEBERG, S. (1989). Role of protein synthesis in the cell division and starvation induced resistance to autolysis of a marine Vibrio during the initial phase of starvation. Journal of General Microbiology 135, 1599-1606.

NYSTRÖM, T., MÅRDÉN, P. \& KJELLEBERG, S. (1986). Relative changes in the incorporation rates of leucine and methionine during starvation survival of two bacteria isolated from marine waters. FEMS Microbiology Ecology 38, 285-292.

Nyström, T., Alber TSON, N. \& KJelleberg, S. (1988). Synthesis of membrane and periplasmic proteins during starvation of a marine Vibrio sp. Journal of General Microbiology 134, 1645-1651.

Nyström, T., Albertson, N. H. \& KJelleberG, S. (1989). Physiological and molecular adaptation to non-growth by marine vibrios. Recent Advances in Microbial Ecology 5, 80-84.

O'FarRell, P. H. (1975). High resolution two-dimensional electrophoresis of proteins. Journal of Biological Chemistry 250, 4007-4021.

POINDEXTER, J. S. (1981a). Oligotrophy: fast and famine existence. Advances in Microbial Ecology 5, 63-89.

PoINDEXTER, J. S. $(1981 b)$. The caulobacters: ubiquitous unusual bacteria. Microbiological Reviews 45, 123-179.

Tempest, D. W. \& NeiJssel, O. M. (1981). Basic Life Sciences 18, 335-356. 